Review Article

\title{
A Comprehensive Review of Cutaneous Manifestations Associated with COVID-19
}

\author{
Hoda Rahimi $\mathbb{D}$ and Zohreh Tehranchinia \\ Skin Research Center, Shahid Beheshti University of Medical Sciences, Tehran, Iran \\ Correspondence should be addressed to Hoda Rahimi; hoda_rahimi@yahoo.com
}

Received 9 May 2020; Revised 30 May 2020; Accepted 25 June 2020; Published 7 July 2020

Academic Editor: Giuseppe Valacchi

Copyright ( 2020 Hoda Rahimi and Zohreh Tehranchinia. This is an open access article distributed under the Creative Commons Attribution License, which permits unrestricted use, distribution, and reproduction in any medium, provided the original work is properly cited.

\begin{abstract}
The novel coronavirus (SARS-CoV-2), the cause of coronavirus 2019 disease (COVID-19) pandemic, is associated with some cutaneous manifestations. Although the cutaneous presentations of COVID-19 are infrequent, it is of great importance for all clinicians to be aware of these manifestations, as it may contribute to sooner and better diagnosis and management of the disease, even in asymptomatic or paucisymptomatic patients. The reported cutaneous manifestations of COVID-19 are various, dispersed, and sometimes confusing. In this article, all reported cases to date were collected and classified under 6 major groups: maculopapular rash, urticaria, chilblain, vesicular lesions, livedo reticularis, and petechiae. Different characteristics of each group were discussed in detail as well.
\end{abstract}

\section{Introduction}

On 31 December 2019, a newly emerged pneumonia caused by a novel coronavirus, named SARS-CoV-2, was announced by China [1]. It spread so rapidly until WHO announced coronavirus 2019 disease (COVID-19) as a pandemic condition on March 11. The firstly reported presentations of COVID-19 were like other viral respiratory infections, including high fever and dry cough. However, it might lead to acute respiratory distress syndrome and the mortality rate was quite high [2]. Since then, a wide spectrum of clinical manifestations have been described, ranging from the absence of any symptoms to fever, cough, dyspnea, diarrhea, ageusia, anosmia, and even cutaneous lesions $[3,4]$. Although the cutaneous manifestations of COVID-19 are infrequent, it is of great importance for all clinicians to be aware of these presentations, as they may contribute to sooner and better diagnosis and management of the disease, even in asymptomatic or paucisymptomatic patients. This could be a valuable help for epidemiological control of the disease, especially in regions where diagnostic kits are limited [5]. On the other hand, the reported cutaneous manifestations of COVID-19 are various, dispersed, and sometimes confusing. Thus, we aimed to review and summarize the different skin lesions, which have been reported in association with COVID-19 to date, in this article.

\section{Methods}

PubMed and Cochrane were searched with the search terms "skin", "cutaneous", and "dermatology", each in combination with "COVID-19" or "SARS-CoV-2". All articles including case reports and original articles from the emergence of the disease (31 December 2019) to the submission of the article (9 May 2020) were included except for one article in which all 6 cases had neither positive PCR test nor common symptoms of COVID-19, and the authors presumed that their cutaneous manifestations may be related to SARS-CoV-2 without any documented evidence [6].

\section{Results}

Different cutaneous lesions have been reported in 451 patients with COVID-19 to date (Table 1). However, it is predictable that the cutaneous lesions have been undoubtedly 


\begin{tabular}{|c|c|c|c|c|c|c|c|c|c|c|c|}
\hline 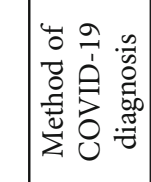 & 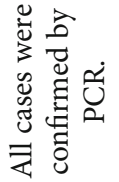 & 蚛 & త్ర & 放 & 范 & 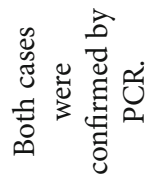 & 苑 & 吕 & 约 & 怘 & 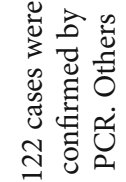 \\
\hline 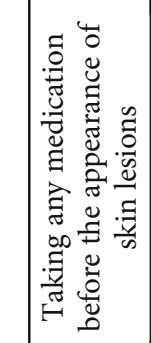 & $\underset{Z}{\Sigma}$ & 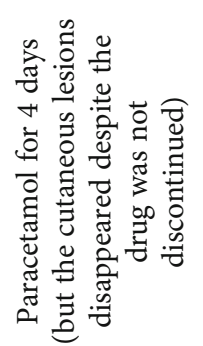 & $\underset{Z}{\Sigma}$ & $\underset{Z}{\Sigma}$ & $\underset{z}{\Sigma}$ & $\sum_{Z}^{\Sigma}$ & 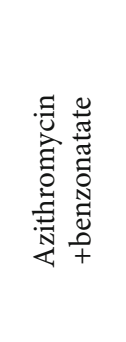 & $\underset{Z}{\Sigma}$ & 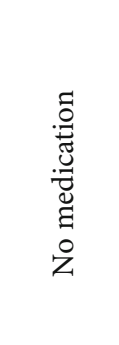 & 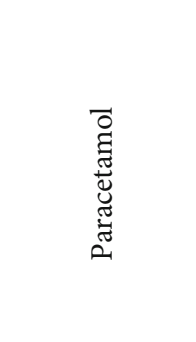 & $\underset{Z}{\Sigma}$ \\
\hline 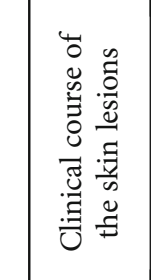 & 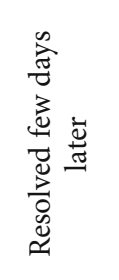 & 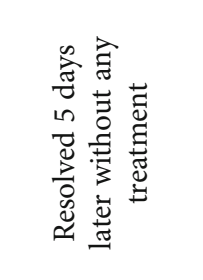 & 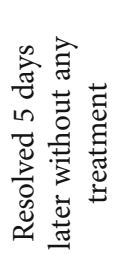 & 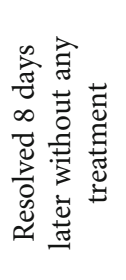 & 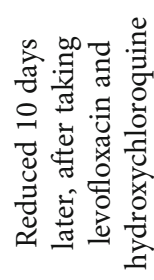 & 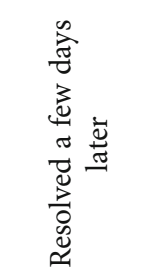 & 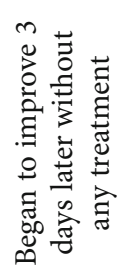 & $\underset{z}{\Sigma}$ & 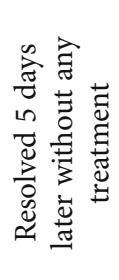 & 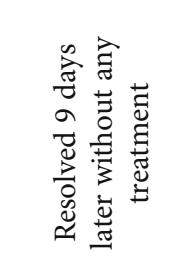 & 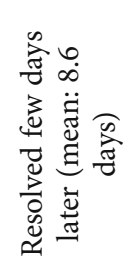 \\
\hline 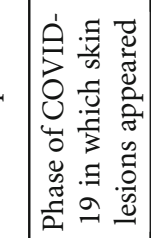 & 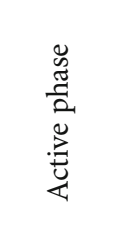 & 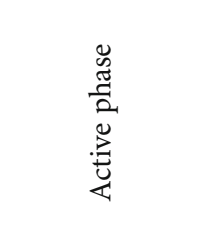 & 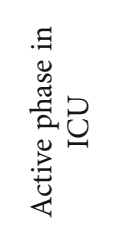 & 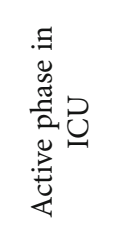 & 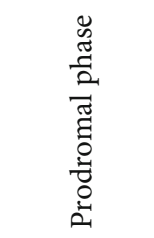 & 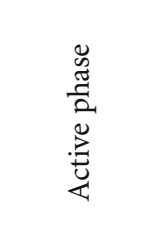 & 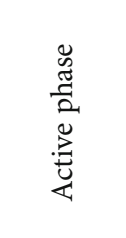 & 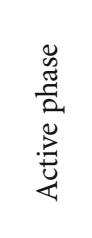 & 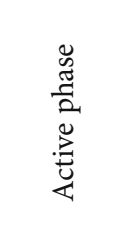 & 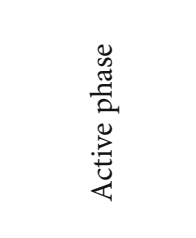 & 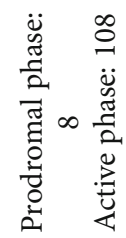 \\
\hline 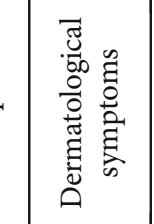 & 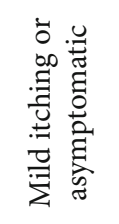 & $\underset{Z}{\Sigma}$ & $\underset{Z}{Z}$ & $\underset{Z}{\Sigma}$ & 品 & 兽 & 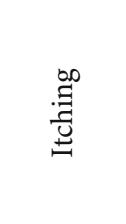 & $\underset{Z}{\Sigma}$ & 兽 & 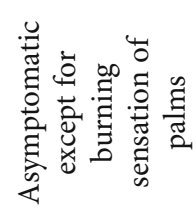 & 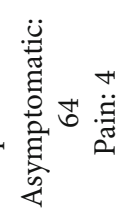 \\
\hline 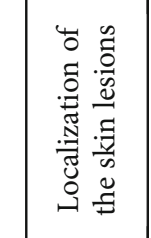 & 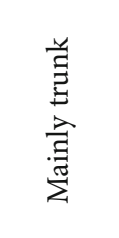 & 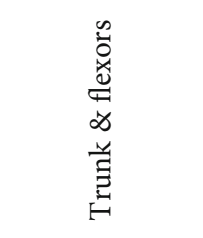 & 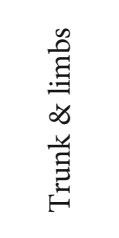 & 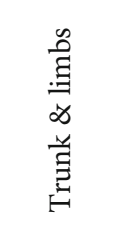 & 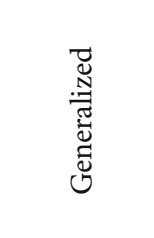 & 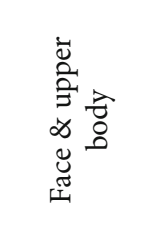 & め & 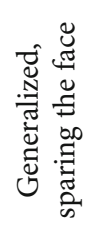 & 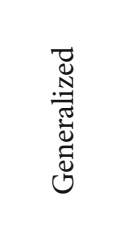 & 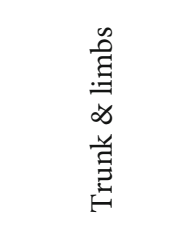 & $\underset{Z}{\Sigma}$ \\
\hline $\begin{array}{l}\text { E } \\
\text { 吾 }\end{array}$ & 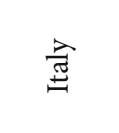 & 䜿 & 氖 & 氖 & $\overrightarrow{\widehat{\Xi}}$ & 䔍 & 岕 & 岕 & $\begin{array}{l}\overrightarrow{\widetilde{E}} \\
\frac{\vec{J}}{\vec{J}} \\
\vec{F}\end{array}$ & 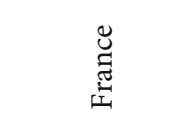 & $\begin{array}{l}\text { ज्ञ } \\
\text { के }\end{array}$ \\
\hline 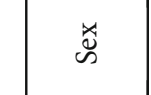 & $\underset{Z}{\Sigma}$ & 山 & $\omega$ & 山 & $\Sigma$ & $\sum_{Z}$ & $\Sigma$ & $\Sigma$ & $\Sigma$ & 山 & 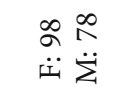 \\
\hline 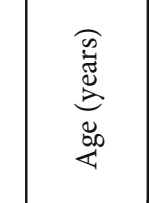 & $\sum_{Z}$ & కే & in & ஓి & in & $\underset{z}{\Sigma}$ & $\stackrel{\infty}{n}$ & ิ & 0 & in & 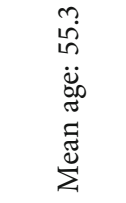 \\
\hline 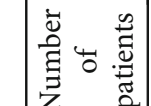 & $\begin{array}{l}\sigma \\
\pm \\
\Xi\end{array}$ & $\Xi$ & $\underset{\Xi}{\Xi}$ & $\underset{\Xi}{\Xi}$ & $\underset{\Xi}{\Xi}$ & $\underset{N}{\stackrel{m}{\Xi}}$ & $\underset{\Xi}{\Xi}$ & $\stackrel{\sqrt[n]{n}}{\Xi}$ & $\underset{\sigma}{\sigma}$ & $\underset{\sigma}{\sigma}$ & $\frac{\Xi}{ٍ}$ \\
\hline 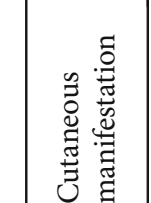 & \multicolumn{11}{|c|}{ 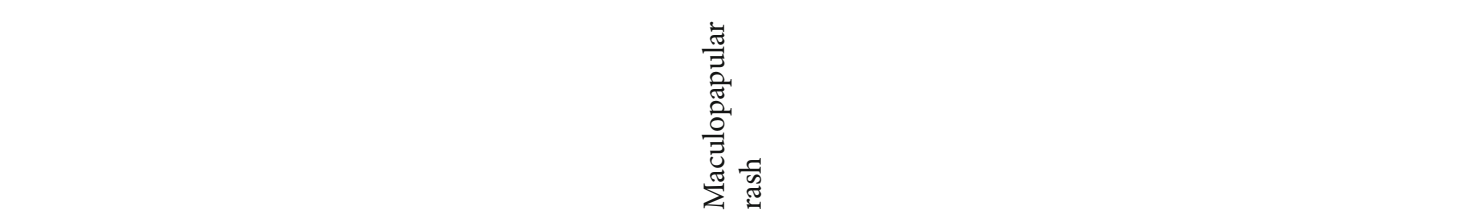 } \\
\hline
\end{tabular}




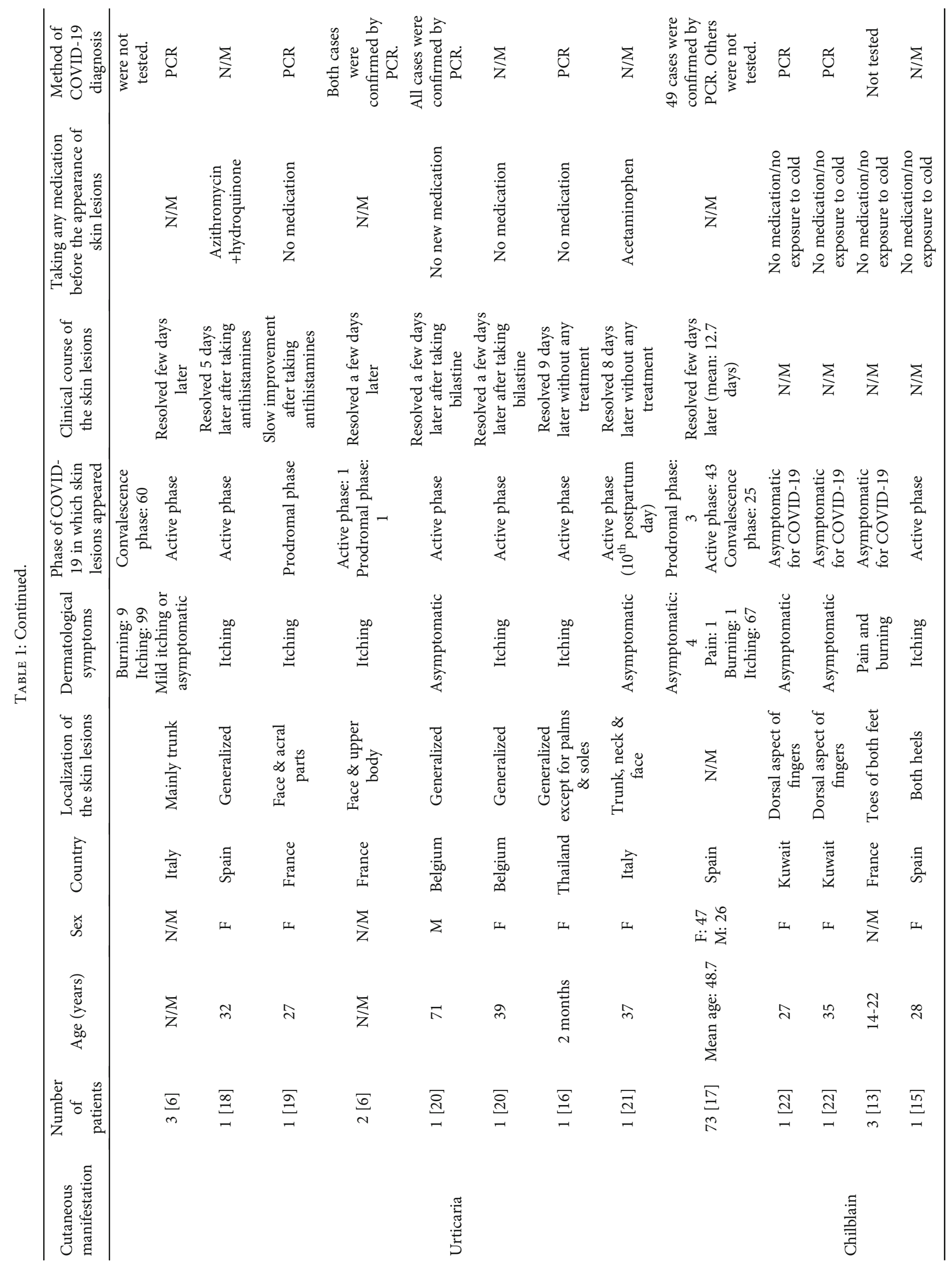




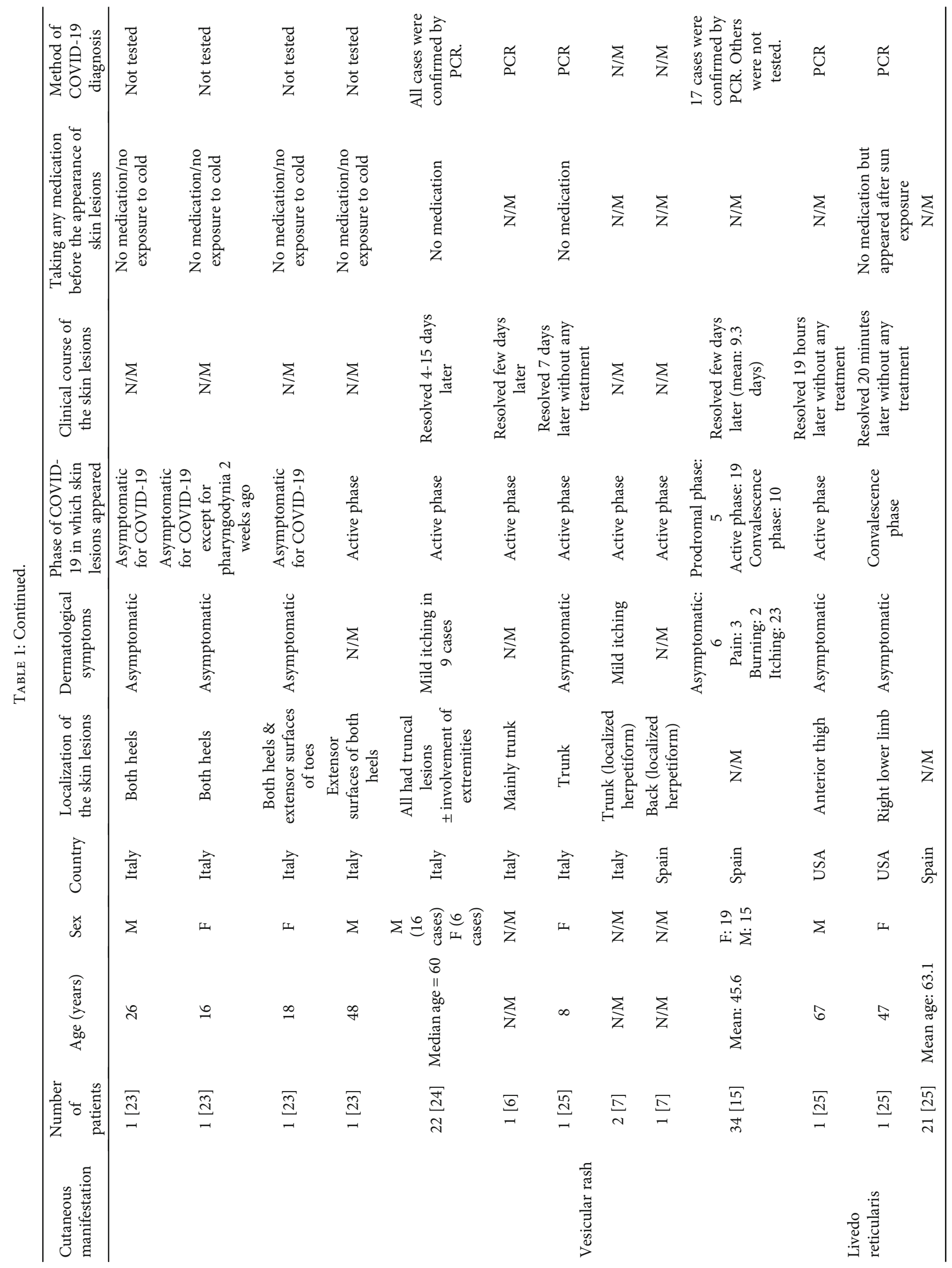




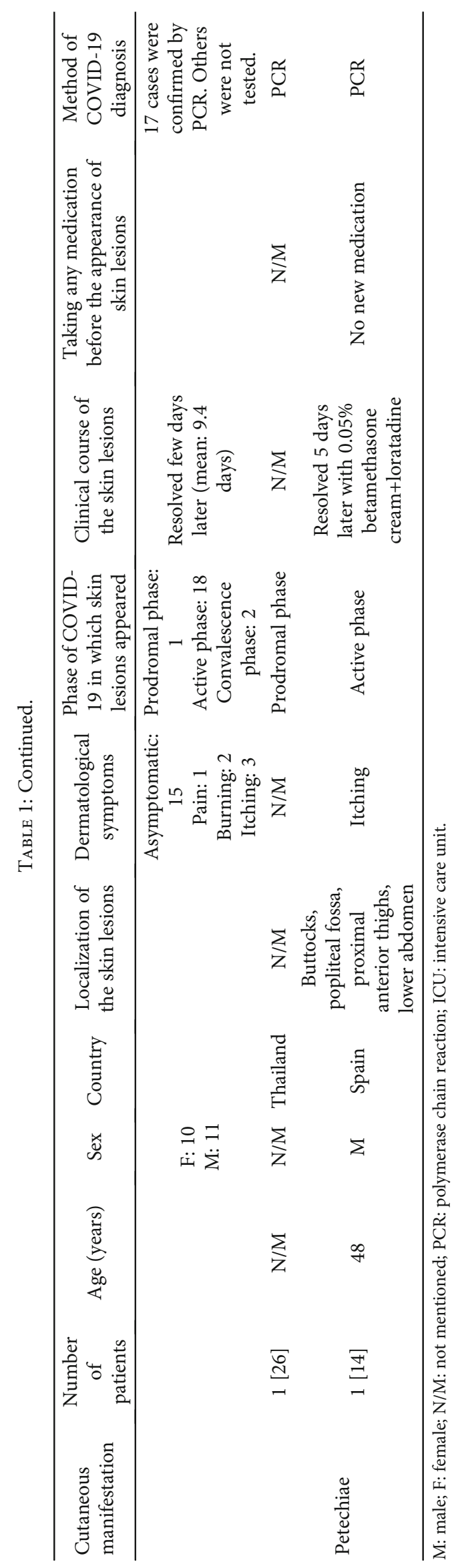


TABLE 2: Classification and characteristics of the cutaneous lesions reported in association with COVID-19.

\begin{tabular}{|c|c|c|c|c|c|c|c|c|}
\hline $\begin{array}{l}\text { Cutaneous } \\
\text { manifestation } \\
\text { (total number } \\
\text { of reported } \\
\text { cases) }\end{array}$ & $\begin{array}{l}\text { Number } \\
\text { of patients }\end{array}$ & $\begin{array}{c}\text { Age, mean (range) } \\
\text { (years) }\end{array}$ & Sex & Country & $\begin{array}{l}\text { Location of } \\
\text { skin lesions }\end{array}$ & $\begin{array}{l}\text { Dermatologic } \\
\text { symptoms }\end{array}$ & $\begin{array}{l}\text { Phase of } \\
\text { COVID-19 in } \\
\text { which skin } \\
\text { lesions } \\
\text { appeared }\end{array}$ & $\begin{array}{l}\text { Method of } \\
\text { COVID-19 } \\
\text { diagnosis }\end{array}$ \\
\hline $\begin{array}{l}\text { Maculopapular } \\
\text { rash }\end{array}$ & 200 & $60.6(6-89)$ & $\begin{array}{c}\text { F: } 102 \\
\text { M: } 82 \\
\text { N/M: } \\
16\end{array}$ & $\begin{array}{l}\text { Spain: } 176 \\
\text { Italy: } 17 \\
\text { France: } 4 \\
\text { USA: } 2 \\
\text { Thailand: } \\
1\end{array}$ & $\begin{array}{c}\text { Trunk: } 14 \\
\text { Generalized } \\
\text { (erythroderma): } \\
8 \\
\text { Face } \& \text { upper } \\
\text { body: } 2 \\
\text { N/M: } 176\end{array}$ & $\begin{array}{c}\text { Asymptomatic: } \\
64 \\
\text { Itching: } 104 \\
\text { Burning: } 10 \\
\text { Pain: } 4 \\
\text { N/M: } 18\end{array}$ & $\begin{array}{c}\text { Prodromal: } 9 \\
\text { Active: } 131 \\
\text { Convalescence: } \\
60\end{array}$ & $\begin{array}{l}146 \text { cases } \\
\text { were } \\
\text { confirmed } \\
\text { by PCR. } \\
\text { Others were } \\
\text { not tested or } \\
\text { N/M. }\end{array}$ \\
\hline Urticaria & 84 & $\begin{array}{c}47.6 \\
\text { (2 months-71 years) } \\
\text { N/M: } 5\end{array}$ & $\begin{array}{c}\text { F: } 52 \\
\text { M: } 27 \\
\text { N/M: } \\
5\end{array}$ & $\begin{array}{l}\text { Spain: } 74 \\
\text { Italy: } 4 \\
\text { France: } 3 \\
\text { Belgium: } \\
2 \\
\text { Thailand: } \\
1\end{array}$ & $\begin{array}{c}\text { Trunk: } 3 \\
\text { Generalized: } 4 \\
\text { Face \& upper } \\
\text { body: } 3 \\
\text { N/M: } 73\end{array}$ & $\begin{array}{c}\text { Asymptomatic: } \\
9 \\
\text { Itching: } 73 \\
\text { Burning: } 1 \\
\text { Pain: } 1\end{array}$ & $\begin{array}{c}\text { Prodromal: } 5 \\
\text { Active: } 52 \\
\text { Convalescence: } \\
25 \\
\text { N/M: } 2\end{array}$ & $\begin{array}{c}57 \text { cases } \\
\text { were } \\
\text { confirmed } \\
\text { by PCR. } \\
\text { Others were } \\
\text { not tested or } \\
\text { N/M. }\end{array}$ \\
\hline Chilblain & 81 & $31.76(14-48)$ & $\begin{array}{c}\text { F: } 53 \\
\text { M: } 25 \\
\text { N/M: } \\
3\end{array}$ & $\begin{array}{l}\text { Spain: } 72 \\
\text { Italy: } 4 \\
\text { France: } 3 \\
\text { Kuwait: } 2\end{array}$ & $\begin{array}{c}\text { Fingers: } 2 \\
\text { Heel \& toes: } 79\end{array}$ & $\begin{array}{c}\text { Asymptomatic: } \\
24 \\
\text { Itching: } 22 \\
\text { Burning: } 11 \\
\text { Pain: } 26\end{array}$ & $\begin{array}{c}\text { Prodromal: } 5 \\
\text { Active: } 26 \\
\text { Convalescence: } \\
42 \\
\text { Asymptomatic } \\
\text { carrier of } \\
\text { COVID-19: } 8\end{array}$ & $\begin{array}{c}31 \text { cases } \\
\text { were } \\
\text { confirmed } \\
\text { by PCR. } \\
\text { Others were } \\
\text { not tested or } \\
\text { N/M. }\end{array}$ \\
\hline Vesicular rash & 61 & Not reportable & $\begin{array}{c}\text { F: } 26 \\
\text { M: } 31 \\
\text { N/M: } \\
4\end{array}$ & $\begin{array}{l}\text { Spain: } 26 \\
\text { Italy: } 35\end{array}$ & $\begin{array}{c}\text { Trunk: } 26 \text { (2 of } \\
\text { them localized \& } \\
\text { herpetiform) } \\
\text { N/M: } 35\end{array}$ & $\begin{array}{c}\text { Asymptomatic: } \\
20 \\
\text { Itching: } 34 \\
\text { Burning: } 2 \\
\text { Pain: } 3 \\
\text { N/M: } 2\end{array}$ & $\begin{array}{c}\text { Prodromal: } 5 \\
\text { Active: } 46 \\
\text { Convalescence: } \\
10\end{array}$ & $\begin{array}{l}41 \text { cases } \\
\text { were } \\
\text { confirmed } \\
\text { by PCR. } \\
\text { Others were } \\
\text { not tested or } \\
\text { N/M. } \\
\end{array}$ \\
\hline $\begin{array}{l}\text { Livedo } \\
\text { reticularis }\end{array}$ & 23 & 62.5 & $\begin{array}{l}\text { F: } 11 \\
\text { M: } 12\end{array}$ & $\begin{array}{l}\text { Spain: } 21 \\
\text { USA: } 2\end{array}$ & $\begin{array}{l}\text { Lower limb: } 2 \\
\text { (unilateral) } \\
\text { N/M: } 21\end{array}$ & $\begin{array}{c}\text { Asymptomatic: } \\
17 \\
\text { Itching: } 3 \\
\text { Burning: } 2 \\
\text { Pain: } 1\end{array}$ & $\begin{array}{c}\text { Prodromal: } 1 \\
\text { Active: } 19 \\
\text { Convalescence: } \\
3\end{array}$ & $\begin{array}{c}19 \text { cases } \\
\text { were } \\
\text { confirmed } \\
\text { by PCR. } \\
\text { Others were } \\
\text { not tested or } \\
\text { N/M. }\end{array}$ \\
\hline Petechiae & 2 & $\begin{array}{c}1 \text { patient: } 48 \\
1 \text { patient: } \mathrm{N} / \mathrm{M}\end{array}$ & $\begin{array}{c}\text { M: } 1 \\
\text { N/M: } \\
1\end{array}$ & $\begin{array}{c}\text { Spain: } 1 \\
\text { Thailand: } \\
1\end{array}$ & $\begin{array}{c}\text { Lower half of the } \\
\text { body: } 1 \\
\text { N/M: } 1\end{array}$ & $\begin{array}{l}\mathrm{N} / \mathrm{M} \\
\text { Itching }\end{array}$ & $\begin{array}{l}\text { Prodromal: } 1 \\
\text { Active: } 1\end{array}$ & $\begin{array}{l}\text { Both cases } \\
\text { were } \\
\text { confirmed } \\
\text { by PCR. }\end{array}$ \\
\hline
\end{tabular}

M: male; F: female; N/M: not mentioned; PCR: polymerase chain reaction.

underdiagnosed due to the lack of dermatology consultations in this pandemic situation. The age of patients ranged between 2 months and 89 years. Patients consisted of 244 females and 178 males, while the gender of 29 patients was not reported. Most reported cases were from Spain (379 pts; 84\%), followed by Italy (51 pts; $11.3 \%$ ), France (10 pts; $2.3 \%$ ), USA (4 pts; 0.9 ), Thailand (3 pts; 0.7\%), Belgium (2 pts; $0.4 \%$ ), and Kuwait (2 pts; $0.4 \%$ ). It is obvious that these data are not compatible with the real prevalence of the disease in different countries, since many dermatological cases might not be reported in the literature due to different reasons. Table 1 shows detailed characteristics of reported patients.

Although the cutaneous presentations of COVID-19 are various, they could be categorized in 6 major groups (Tables 1 and 2).

(1) Maculopapular rash. Maculopapular rash, with or without pruritus, was the most common cutaneous manifestation of COVID-19, presented in 200 patients (44.4\%). The mean age of the patients in this group was 60.4 years (range: 6-89 
years). More than half of the patients were female, and the most common localization of the lesions was the trunk. Although $35 \%$ of patients were asymptomatic, the most frequent symptom was itching which presented in $57 \%$ of cases. This kind of rash is mostly observed in the active phase of the disease.

(2) Urticaria. The second most frequent skin rash in COVID19 patients was urticaria which appeared in 84 patients (18.6\%). The mean age of the cases was 47.6 years, while the youngest patient aged 2 months and the eldest 71 years. Again, females were dominant (66\%), Spain reported the most number of cases, and the rash appeared mostly within the active phase of the infection.

(3) Chilblain. Chilblain occurred in 81 patients (18\%) without any history of exposure to cold. This group had some especial characteristics which made it different from the others; it mostly presented in younger patients with a mean age of 31.7 years, and females were involved significantly more than males (68\% vs. $32 \%$ ). Moreover, in contrast to other cutaneous manifestations, which appeared mostly in the active phase, chilblain often presented later in the course of the disease (after the complete recovery, in half of the patients). Furthermore, approximately $10 \%$ of the patients were asymptomatic carriers of COVID-19 who had only chilblain and positive PCR test, without any symptom of COVID-19. None of the cutaneous manifestations was reported in asymptomatic carriers, except for chilblain. Its distribution was, as usual, in acral parts. However, the heels and toes were affected significantly more than the fingers $(97.5 \%$ vs. $2.5 \%)$. The most frequent symptom was pain $(32.1 \%)$.

(4) Vesicular lesions. Vesicular lesions, reported in 61 patients (13.5\%), usually manifested like chicken pox, consisting of pruritic papulovesicular rashes involving the trunk mostly. However, three patients presented with localized vesicular lesions which was herpetiform [7]. Vesicular rashes were reported only from Italy and Spain, often in the active phase of the disease.

(5) Livedo reticularis. Livedo reticularis was reported in 23 patients $(5.1 \%)$ as generally asymptomatic lesions, affecting both genders almost equally. In two cases, it was unilateral, resolving in few hours without any treatment [8]. They were in contrast with the usual bilateral distribution of the common livedo reticularis which does no subside spontaneously.

(6) Petechiae. To date, only 2 cases $(0.4 \%)$ of petechiae were reported in association with COVID-19 $[9,10]$, one of which was firstly misdiagnosed and mistreated as dengue [10].

As it may be noticed, cutaneous lesions of COVID-19 may manifest in different forms, in every age and sex, and involve every part of the body. However, the involvement of mucosa has not been reported yet, except for a case of oral herpes simplex virus- 1 reactivation in an intubated patient, which seemed to be secondary to the intubation rather than a presentation of the virus [13]. In all groups, pruritus was the most common symptom, except for chilblain which was more associated with pain than pruritus. Generally, the skin lesions were observed in the active phase of infection $(61 \%$ of cases) and subsided within few days without any treatment. Although the appearance of skin rash in the prodromal phase or asymptomatic carriers was scarce, it is of great importance for all clinicians to keep in mind that cutaneous lesions might be the only symptom of COVID-19, as it would contribute to sooner diagnosis and management of the patients/carriers and better control of the disease spreading. From 451 reported patients, only 296 cases were confirmed by polymerase chain reaction (PCR) test. Due to the lack of the diagnostic kits in this pandemic period, they were performed only for hospitalized or severe cases in most countries. That is why all cases did not have a documented diagnosis and suspected cases were included as well. However, it should be noticed that (1) many of these suspected cases had other typical signs and symptoms of COVID-19; (2) many of them had positive family history of COVID-19 or close contact with infected patients; and (3) almost in all of these cases there was no other explanation for their cutaneous lesions except for COVID-19. Another important point which remained controversial is that whether these cutaneous presentations have any correlation with the severity of the disease or could be used as a prognostic factor. Although Galván Casas et al. reported that chilblain was associated with less severe disease, and livedo reticularis was associated with the most severe forms of the disease [17], the role of confounding factors such as age should be noticed, as well. However, Recalcati reported no correlation between cutaneous presentations and disease severity [6].

\section{Conclusion}

Although these data do not prove that COVID-19 was the definite cause of these skin lesions, they demonstrate that cutaneous lesions should be considered in the spectrum of presentations potentially associated with this infection. In particular, some cutaneous manifestations such as chilblain without any explanation may warn about asymptomatic virus carriers. However, further investigations should be carried out to evaluate the relation between skin lesions and COVID-19.

\section{Conflicts of Interest}

The authors declare that they have no conflicts of interest.

\section{References}

[1] A. L. Phelan, R. Katz, and L. O. Gostin, "The novel coronavirus originating in Wuhan, China," JAMA, vol. 323, no. 8, p. 709, 2020.

[2] Q. Li, X. Guan, P. Wu et al., "Early transmission dynamics in Wuhan, China, of novel coronavirus-infected pneumonia," New England Journal of Medicine, vol. 382, no. 13, pp. 11991207, 2020.

[3] H. A. Rothan and S. N. Byrareddy, "The epidemiology and pathogenesis of coronavirus disease(COVID-19) outbreak," Journal of Autoimmunity, vol. 109, p. 102433, 2020. 
[4] J. R. Lechien, C. M. Chiesa-Estomba, D. R. De Siati et al., "Olfactory and gustatory dysfunctions as a clinical presentation of mild-to-moderate forms of the coronavirus disease (COVID-19): a multicenter European study," European Archives of Oto-Rhino-Laryngology, 2020.

[5] A. D. Usher, "COVID-19: learning from experience," The Lancet, vol. 395, no. 10229, p. 1011, 2020.

[6] S. Recalcati, "Cutaneous manifestations in COVID-19: a first perspective," Journal of the European Academy of Dermatology and Venereology, vol. 34, no. 5, pp. e212-e213, 2020.

[7] A. Tammaro, G. A. R. Adebanjo, F. R. Parisella, A. Pezzuto, and J. Rello, "Cutaneous manifestations in COVID-19: the experiences of Barcelona and Rome," Journal of the European Academy of Dermatology and Venereology, 2020.

[8] I. F. Manalo, M. K. Smith, J. Cheeley, and R. Jacobs, "A dermatologic manifestation of COVID-19: transient livedo reticularis," Journal of the American Academy of Dermatology, 2020.

[9] B. Ahouach, S. Harent, A. Ullmer et al., "Cutaneous lesions in a patient with COVID-19: are they related?," The British Journal of Dermatology, 2020.

[10] B. Joob and V. Wiwanitkit, "COVID-19 can present with a rash and be mistaken for dengue," Journal of the American Academy of Dermatology, vol. 82, no. 5, p. e177, 2020.

[11] A. Mahé, E. Birckel, S. Krieger, C. Merklen, and L. Bottlaender, "A distinctive skin rash associated with coronavirus disease 2019?," Journal of the European Academy of Dermatology and Venereology, vol. 34, no. 6, pp. e246-e247, 2020.

[12] P. Vezzoli, S. Recalcati, V. Girgenti, L. Venegoni, S. Veraldi, and E. Berti, "Cutaneous Lymphoid Hyperplasia Associated with Leishmania panamensis Infection," Acta Dermato Venereologica, vol. 90, no. 4, pp. 418-419, 2010.

[13] M. Hedou, F. Carsuzaa, E. Chary, E. Hainaut, F. CazenaveRoblot, and M. Masson Regnault, "Comment on "Cutaneous manifestations in COVID-19: a first perspective " by Recalcati S," Journal of the European Academy of Dermatology and Venereology, 2020.

[14] D. J. Najarian, "Morbilliform exanthem associated with COVID-19," JAAD Case Reports., vol. 6, no. 6, pp. 493-494, 2020.

[15] M. Hunt and C. Koziatek, "A case of COVID-19 pneumonia in a young male with full body rash as a presenting symptom," Clinical Practice and Cases in Emergency Medicine, vol. 4, no. 2, pp. 219-221, 2020.

[16] M. Morey-Olivé, M. Espiau, M. Mercadal-Hally, E. Lera-Carballo, and V. García-Patos, "Manifestaciones cutaneas en contexto del brote actual de enfermedad por coronavirus 2019," Anales de Pediatría (English Edition), vol. 92, no. 6, pp. 374375, 2020.

[17] C. Galván Casas, A. Català, G. Carretero Hernández et al., "Classification of the cutaneous manifestations of COVID19: a rapid prospective nationwide consensus study in Spain with 375 cases," The British Journal of Dermatology, 2020, [Epub ahead of print].

[18] D. Fernandez-Nieto, D. Ortega-Quijano, G. Segurado-Miravalles, C. Pindado-Ortega, M. Prieto-Barrios, and J. JimenezCauhe, "Comment on: Cutaneous manifestations in COVID19: a first perspective. Safety concerns of clinical images and skin biopsies," Journal of the European Academy of Dermatology and Venereology, vol. 34, no. 6, pp. e252-e254, 2020, Epub ahead of print.
[19] D. Henry, M. Ackerman, E. Sancelme, A. Finon, and E. Esteve, "Urticarial eruption in COVID-19 infection," Journal of the European Academy of Dermatology and Venereology, vol. 34, no. 6, pp. e244-e245, 2020.

[20] C. van Damme, E. Berlingin, S. Saussez, and O. Accaputo, "Acute urticaria with pyrexia as the first manifestations of a COVID-19 infection," Journal of the European Academy of Dermatology and Venereology, 2020.

[21] G. Paolino, V. Canti, S. R. Mercuri, P. Rovere Querini, M. Candiani, and F. Pasi, "Diffuse cutaneous manifestation in a new mother with COVID-19 (SARS-Cov-2)," International Journal of Dermatology, vol. 59, no. 7, pp. 874-875, 2020.

[22] A. Alramthan and W. Aldaraji, "Two cases of COVID-19 presenting with a clinical picture resembling chilblains: First report from the Middle East," Clinical and Experimental Dermatology, 2020.

[23] G. Tosti, A. Barisani, P. Queirolo et al., "Skin signs resembling vascular acrosyndromes during the COVID-19 outbreak in Italy," Clinical and Experimental Dermatology, 2020.

[24] A. V. Marzano, G. Genovese, G. Fabbrocini et al., "Varicellalike exanthem as a specific COVID-19-associated skin manifestation: Multicenter case series of 22 patients," Journal of the American Academy of Dermatology, vol. 83, no. 1, pp. 280-285, 2020.

[25] G. Genovese, C. Colonna, and A. V. Marzano, "Varicella-like exanthem associated with COVID-19 in an 8-year-old girl: a diagnostic clue?," Pediatric Dermatology, 2020.

[26] S. Recalcati, T. Barbagallo, L. A. Frasin et al., "Acral cutaneous lesions in the time of COVID-19," Journal of the European Academy of Dermatology and Venereology, 2020. 